\title{
Effects of Gypsum and Zeolite on Nutrient Uptake and Shallot (Allium ascalonium L.) Growth on Irrigated Saline Entisol
}

\author{
Rahayu*, Jauhari Syamsiyah and Livia Dewi \\ Department of Soil Science, Faculty of Agriculture, Universitas Sebelas Maret, Jl. Ir. Sutami No.36A, Jebres, \\ Surakarta, Jawa Tengah 57126, Indonesia \\ *e-mail: rahayu_pn@staff.uns.ac.id
}

Received November 24, 2018; Revised March 28, 2019; Accepted April 30, 2019

\begin{abstract}
Entisol is a weakly-developed soil with a diverse fertility, and has a potency for shallot cultivation. The central of shallot cultivation in Indonesia is in coastal areas which have a limiting factor of high soil salinity. High salinity will cause the nutrient uptake and plant growth disrupted. Zeolite and gypsum application can be a potential option to overcome the impact of high salinity. This study was arranged in a Completely Randomized Design (CRD) in a pot experiment with the treatments of combinations of shallot cultivars (Brebes $=V 1$, Purbalingga $=$ V2, Pemalang $=V 3$ ) and soil amendments (gypsum $25 \mathrm{Mg} \mathrm{ha}^{-1}=\mathrm{G}$, zeolite $15 \mathrm{Mg} \mathrm{ha}^{-1}=\mathrm{Z}$, and Control=K). Each pot contained of $15 \mathrm{~kg}$ soil was irrigated by $1 \mathrm{~L}$ saline water of $2 \mathrm{dS} \mathrm{m}^{-1}$ every day. The results showed that the irrigation and incubation with saline water increased $\mathrm{pH}, \mathrm{EC}$ and SAR of soil, whereas zeolite and gypsum application decreased $\mathrm{pH}, \mathrm{EC}$, SAR. The application of gypsum significantly increased the nutrient uptake, therefore significantly increased the bulb diameter, and fresh and dry weight of shallot bulbs. The effects of amendements on the growth of shallot cultivars is different. Application of gypsum and zeolite showed better effect on cultivar Purbalingga, whereas the highest plant was maesured in the treatment of zeolite on cultivar Pemalang.
\end{abstract}

Keywords: Gypsum, shallot, salinity, zeolit

\begin{abstract}
ABSTRAK
Entisol merupakan tanah dengan perkembangan yang lemah dengan kesuburan tanah yang beragam, dan memiliki potensi untuk budidaya bawang merah. Pusat budidaya bawang merah di Indonesia terletak di daerah pantai dengan faktor pembatas salinitas tanah yang tinggi. Salinitas tanah yang tinggi dapat menyebabkan terganggunya serapan unsur hara dan pertumbuhan tanaman. Aplikasi zeolit dan gipsum dapat menjadi opsi yang potensial untuk mengatasi pengaruh salinitas yang tinggi. Penelitian ini disusun dalam Rancangan Acak Lengkap (RAL) dalam percobaan pot dengan perlakuan yang merupakan kombinasi antara kultivar bawang merah (Brebes $=$ V1, Purbalingga $=$ V2, Pemalang =V3) dan aplikasi bahan pembenah tanah (gypsum $25 \mathrm{Mg} \mathrm{ha}^{-1}=\mathrm{G}$, zeolite $15 \mathrm{Mg} \mathrm{ha}^{-1}=\mathrm{Z}$, dan kontrol $=\mathrm{K}$ ). Setiap pot diisi dengan $15 \mathrm{~kg}$ tanah dan diirigasikan dengan $1 \mathrm{~L}$ air salin dengan salinitas $2 \mathrm{dS} \mathrm{m}^{-1}$ setiap hari. Hasil penelitian menunjukkan bahwa irigasi dan inkubasi dengan air salin meningkatkan $\mathrm{pH}, \mathrm{EC}$ (Electrical Conductivity), dan SAR (Sodium Adsorption Ratio) tanah Entisol, sedangkan aplikasi zeolit dan gipsum menurunkan pH, EC dan SAR. Aplikasi gispsum meningkatkan secara signifikan serapan unsur hara, sehingga meningkatkan secara signifikan diamater umbi bawang merah dan berat basah dan berat kering umbi bawang merah. Pengaruh aplikasi pembenah tanah terhadap pertumbuhan tanaman bawang merah berbeda antar kultivar. Aplikasi gipsum dan zeolit menunjukkan pengaruh yang lebih baik pada kultivar Purbalingga, sedangkan tinggi tanaman tertinggi terukur pada perlakuan zeolit pada kultivar Pemalang.
\end{abstract}

Kata kunci: Bawang merah, gipsum, salinitas, zeolit

\section{INTRODUCTION}

Entisol is a weakly-developed soil, with potential fertility varies from highly productive for

J Trop Soils, Vol. 24, No. 2, 2019: 73-81

ISSN 0852-257X; E-ISSN 2086-6682 shallot cultivation such as alluvial soils in floodplain, to low fertility on steep slopes or sandy areas (Buol 2005). According to Firmansyah and Sumarni (2013), Brebes is one of the central of shallot cultivation in Central Java, with alluvial soil types. Brebes has a shallot harvesting area of 26,645 ha in 2015-2016 (Central Bureau of Statistics of Central 
Java Province 2017). The problem that is often experienced by shallot farmers in the northern coast region is the high level of soil salinity because of the intrusion of sea water that enters the irrigation canals. According to Hendrayana (2002) salinity occurs in the northern coast region due to the presence of sea water enters the plains and cannot be restrained, causing salt accumulation in the soil surface. Salinity is a condition of soil with high $\mathrm{Na}^{+}$ concentration that can affect plant growth (Agus and Subiksa 2006). Yield of shallot planted in saline soils is about $18.39 \%$ lower than in acidic sulphate soils (Koswara 2007). High level of salinity causes plants to have low ability to absorb water from the soil, which can cause restricted plant growth and died (Provin and Pitt 2017). The soil salinity of 2 $\mathrm{dS} \mathrm{m}^{-1}$ can reduce shallot yield by $12.82 \%$ (Cardon et al. 2003).

High salinity in soil is very detrimental, so the mitigation measures must be done. Saline soil management that has been carried out to mitigate the impact of soil salinity includes utilization of mycorrhiza to prevent $\mathrm{Na}^{+}$translocation from roots to shoots (Hadjah 2014), irrigation techniques using the pool-flow method (Kristanto and Purwarno 2017), and application of biochar and manure (Muharam and Saefudin 2016). The mechanism of improving soil salinity is by additional $\mathrm{Ca}$ and $\mathrm{Mg}$ that can replace $\mathrm{Na}$ ions in soil exchange complex and leach the $\mathrm{Na}$ into a deeper soil profile (Jarman 2013). The common ameliorant used for saline soil is gypsum $\left(\mathrm{CaSO}_{4}\right)$. Gypsum can be used for saline soil reclamation because gypsum can increase soil aggregation, soil percolation, and improve soil $\mathrm{pH}$ (Franzen et al. 2006). Haisheng et al. (2008) reported that gypsum can increase $\mathrm{Ca}^{2+}$ content and replace $\mathrm{Na}^{+}$to improve soil permeability. Size of aggregate in soil profile has correlation to the effectiveness of gypsum amendment in reducing exchangeable Na percentage (Lebron et al. 2006). Effectiveness of gypsum amendments depends on the soil water electrolyte and $\mathrm{Ca}$ concentrations resulted from gypsum dissolution, and on the efficiency of the $\mathrm{Na}-\mathrm{Ca}$ soil exchange process (Amezketa et al. 2005). Application of gypsum decreased $\mathrm{Na}$ accumulation in soil applied with peat, however, increased rates of gypsum did not affect sodium content in the surface soil, but reduced the ratio of sodium to the other salts (Rahayu et al. 2011).

Zeolite is a hydrated alumina silicate crystal that contains three-dimensional alkaline or alkaline earth cations, acidic and has a molecular-sized pore (Atikah 2017). Zeolite can be utilized as a soil amendment that can increase soil porosity (Micu et al. 2005), and play a role in reducing $\mathrm{N}$ leaching. According to Warmada and Titisari (2004), if there is a saturation of $\mathrm{Na}^{+}$from $\mathrm{NaCl}$, the $\mathrm{Na}$ will be adsorbed by zeolite to re-form Na-Zeolite $\left(\mathrm{Na}_{2} \mathrm{Al}_{2} \mathrm{Si}_{3} \mathrm{O}_{10} 2 \mathrm{H}_{2} \mathrm{O}\right)$. Wang et al. (2012) reported that application of zeolite to saline soils with a solid ratio of $30 \%$ by weight of the soil can reduce sodium content from $563.0 \mathrm{ppm}$ to $182.7 \mathrm{ppm}$. In addition, plant growth is also influenced by nutrient uptake, especially nitrogen, phosphorus and potassium that are essential nutrients (Sudarmi 2013). This study examined the effects of gypsum and zeolite amendments on N, P, K uptake and shallot growth on Entisol irrigated by saline water.

\section{MATERIALS AND METHODS}

\section{Research Design and Treatments}

This study was arranged in a Completely Randomized Design. A pot experiment was carried out from June to December 2017 in the Experimental Station of the Faculty of Agriculture, Sebelas Maret University. The treatments included (1) the soil amendments consisting of Gypsum (G), Zeolite (Z), and Control/without amendments (K); and (2) the shallot cultivars consisting of Brebes (V1), Purbalingga (V2) and Pemalang (V3). The soil used for the pot experiment was taken from the top soil of 0-30 cm of Entisol from Plesungan, Karanganyar, Central Java with the latitude of 7031' 54's; $110^{\circ} 51$ ' $40^{\prime \prime} \mathrm{E}$. The properties of the soil is presented in Table 1. The pot used was $30 \mathrm{~cm}$ in diameter, filled with soil as much as $15 \mathrm{~kg} \mathrm{pot}^{-1}$ and replicated 3 times. The soil was made saline by irrigating $2 \mathrm{dS}$ $\mathrm{m}^{-1}$ of saline water at field capacity and incubated for 2 weeks, followed by the addition of zeolite $75 \mathrm{~g}$ pot $^{-1}$ (CEC $223.15 \mathrm{cmol}(+) \mathrm{kg}^{-1}$ ) and gypsum 125 $\mathrm{g} \mathrm{pot}^{-1}\left(\mathrm{CaSO}_{4} \cdot 2 \mathrm{H}_{2} \mathrm{O} 93.87 \%\right)$ (Table 2). Fertilizers were applied at week 2 and week 4, based on the shallot fertilization recommendation by SNI (Indonesian National Standard), i.e. $250 \mathrm{~kg} \mathrm{ha}^{-1}$ urea, $180 \mathrm{~kg} \mathrm{ha}^{-1} \mathrm{ZA}, 300 \mathrm{~kg} \mathrm{ha}^{-1} \mathrm{SP}-36$, and 200 $\mathrm{kg} \mathrm{ha}^{-1} \mathrm{KCl}$. Shallot bulbs were planted at the soil moisture level of field capacity. Irrigation was done by applying saline water with the salinity of $2 \mathrm{dS} \mathrm{m}^{-}$ ${ }^{1}$, obtained from a mixture of $1.28 \mathrm{gr}$ of salt with $1 \mathrm{~L}$ of water. The saline water was applied as much as $1 \mathrm{~L} \mathrm{pot}^{-1}$ day $^{-1}$ to reach field capacity of the soil.

\section{Soil and Plant Analysis}

Soil samples were taken before planting and after harvest for soil characteristic and salt accumulation analyses. The parameters measured were plant height (every week until the maximum 
Table 1. Soil characteristics before and after incubation.

\begin{tabular}{|c|c|c|}
\hline Soil Chemical Properties & Before Incubation & After Incubation \\
\hline $\mathrm{pH}$ & $7.19\left(\mathrm{~N}^{*}\right)$ & $7.29\left(\mathrm{~N}^{*}\right)$ \\
\hline Organic-C (\%) & $1.14(\mathrm{~L})$ & $1.18(\mathrm{~L})$ \\
\hline Total-N (\%) & $0.20(\mathrm{~L})$ & $0.17(\mathrm{~L})$ \\
\hline Available-P (ppm) & $2.84(\mathrm{VL})$ & $4.48(\mathrm{VL})$ \\
\hline Available-K $\left(\mathrm{me} 100 \mathrm{~g}^{-1}\right)$ & $0.67(\mathrm{M})$ & $1.21(\mathrm{H})$ \\
\hline Cation Exchange Capacity $\left(\mathrm{cmol}(+) \mathrm{kg}^{-1}\right)$ & $18.04(\mathrm{M})$ & $18.31(\mathrm{M})$ \\
\hline Exchangeable $\mathrm{Na}\left(\mathrm{cmol}(+) \mathrm{kg}^{-1}\right)$ & $0.12(\mathrm{~L})$ & $12.09(\mathrm{VH})$ \\
\hline Exchangeable $\mathrm{Ca}\left(\mathrm{cmol}(+) \mathrm{kg}^{-1}\right)$ & $12.03(\mathrm{H})$ & $1.12(\mathrm{~L})$ \\
\hline Exchangeable $\mathrm{Mg}\left(\mathrm{cmol}(+) \mathrm{kg}^{-1}\right)$ & $0.93(\mathrm{~L})$ & $0.35(\mathrm{~L})$ \\
\hline Base saturation (\%) & $78.99(\mathrm{H})$ & $76.59(\mathrm{H})$ \\
\hline Electrical Conductivity $\left(\mathrm{dS} \mathrm{m}^{-1}\right)$ & $0.14(\mathrm{VL})$ & $260.76(\mathrm{M})$ \\
\hline Sodium Adsorption Ratio (me $100 \mathrm{~g}^{-1}$ ) & $0.05(\mathrm{~L})$ & $12.11(\mathrm{VH})$ \\
\hline Texture & Loam & Loam \\
\hline
\end{tabular}

Note: ${ }^{*}$ Criteria according to Balai Penelitian Tanah (2009): VL = Very Low; $\mathrm{L}=$ Low; $\mathrm{M}=$ Moderate; $\mathrm{H}=$ High; VH = Very High; $\mathrm{N}=$ Neutral.

plant growth), bulb diameter, wet weight of bulbs and dry weight of bulbs. The soil characteristics were analyzed according to the procedures proposed by Evianti and Sulaiman (2012), consisting of $\mathrm{pH}$ (soil: solution ratio 1:2.5), Electrical Conductivity (soil:solution ratio 1:5), and organic-C (Walkey and Black). Analysis of N uptake (Kjedhal), $\mathrm{P}$ and $\mathrm{K}$ uptake (wet ignition using $\mathrm{HNO}_{3}$ and $\mathrm{HClO}_{4}$ ) by the shallot plants were also determined.

\section{Data Analysis}

The data were analyzed using F-variance test at 5\% significance level and continued by Duncan's Multiple Range Test (DMRT). Correlation test was also performed to evaluate the relationship between the selected parameters.

\section{RESULTS AND DISCUSSION}

\section{Effects of Gypsum and Zeolite on Soil Characteristics}

Initial soil $\mathrm{pH}$, Electrical Conductivity (EC) and Sodium Adsorption Ratio (SAR) increased after the salinity condition of the soil was reached and after the incubation (Table 1). The increase of $\mathrm{pH}$ was due to an increase of cation concentration that triggered the release of $\mathrm{H}^{+}$into soil solution. According to Lubis et al. (2013) an increase in cation activity will result in an increase of soil $\mathrm{pH}$. The increase of EC is thought to be due to the application of saline water irrigation $\left(2 \mathrm{dS} \mathrm{m}^{-1}\right)$ during the incubation. The increase in soluble salt concentration will increase the EC (Eviati and Sullaiman 2012).

Table 2. Water content and CEC of gypsum and zeolite.

\begin{tabular}{clll}
\hline No & Parameter & Gypsum $\left(\mathrm{CaSO}_{4}\right)$ & Zeolit \\
\hline 1. & water content $(\%)$ & 1.91 & 6.79 \\
2. & CEC $\left(\mathrm{cmol}(+) \mathrm{kg}^{-1}\right)$ & 93.87 & 223.15 \\
\hline
\end{tabular}

Table 3. The effects of application of gypsum and zeolite on the soil properties.

\begin{tabular}{lccc}
\hline \multicolumn{1}{c}{ Soil Amandement } & $\mathrm{pH}$ & $\mathrm{EC}\left(\mathrm{dS} \mathrm{cm}^{-1}\right)$ & SAR $\left(\mathrm{me}^{-100 \mathrm{~g}^{-1}}\right)$ \\
\hline${\text { Gypsum }\left(25 \mathrm{Mg} \mathrm{ha}^{-1}\right)}_{\text {Zeolit }\left(15 \mathrm{Mg} \mathrm{ha}^{-1}\right)}^{6.68 \mathrm{c}}$ & $0.17 \mathrm{~b}$ & $0.24 \mathrm{~b}$ \\
Without treatment & $7.37 \mathrm{~b}$ & $0.23 \mathrm{~b}$ & $0.20 \mathrm{~b}$ \\
\hline
\end{tabular}

Note: The numbers followed by the same letters in the same column are not significantly different according to DMRT at 5\% significance level. 


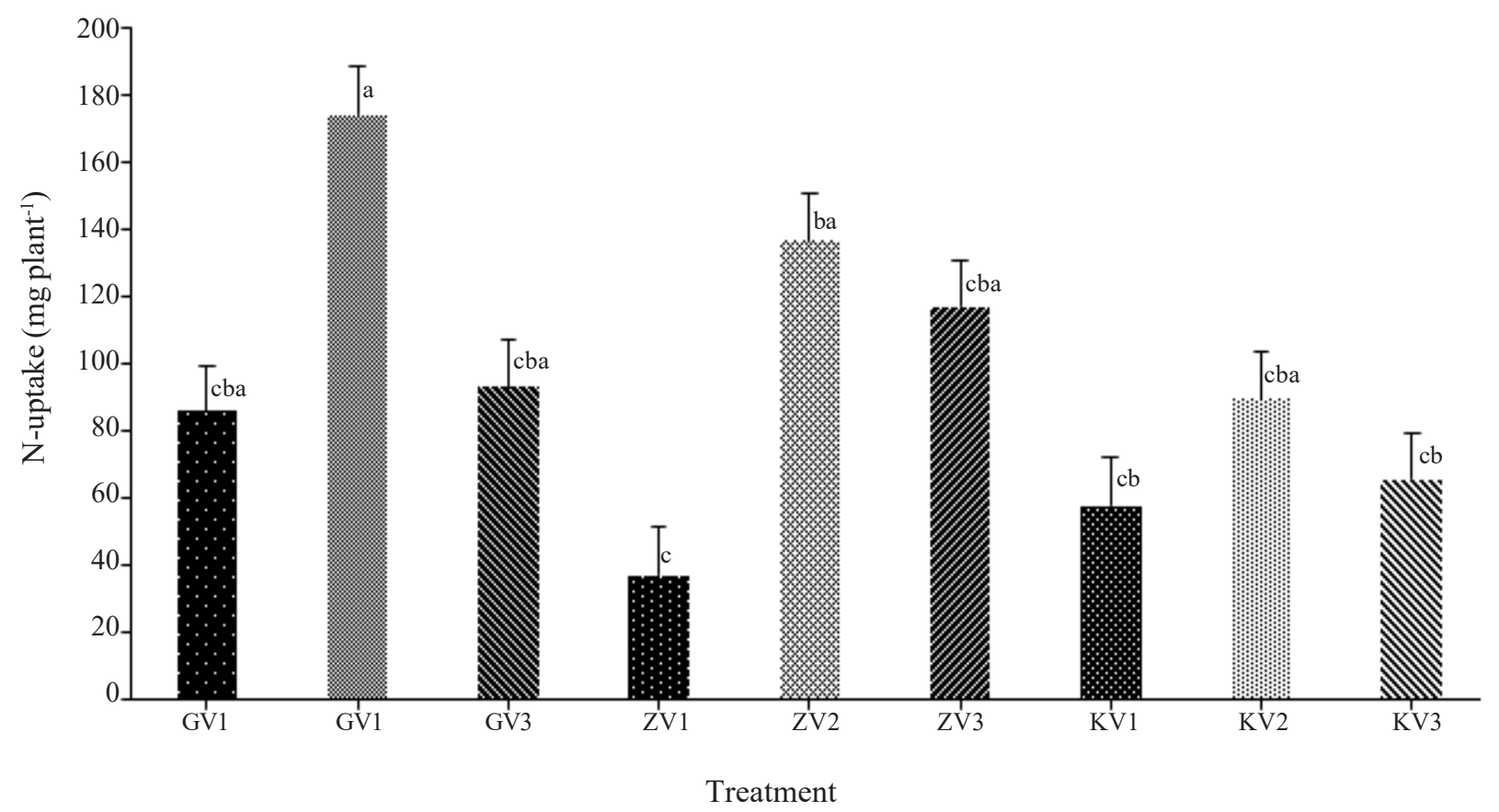

Figure 1. The uptake of $\mathrm{N}$ by shallot plants due to the application of gypsum and zeolite. The numbers above bars followed by the same letters are not significantly different according to DMRT at 5\% significance level. $\mathrm{G}=$ Gypsum $\left(25 \mathrm{Mg} \mathrm{ha}^{-1}\right), \mathrm{Z}=$ Zeolit $\left(15 \mathrm{Mg} \mathrm{ha}^{-1}\right), \mathrm{K}=$ without treatment, $\mathrm{V} 1$ $=$ cultivar Brebes, $\mathrm{V} 2$ = cultivar Purbalingga, V3 = cultivar Pemalang.

Table 1 showed that after the incubation, the SAR increased. The increase of $\mathrm{Na}^{+}$concentration was due to the application of saline water irrigation. Rosmarkam and Yuwono (2014) showed that the increasing levels of Na lead to higher values of SAR. Application of gypsum showed a significant effect $(p<0.05)$ on soil $\mathrm{pH}$ and EC. Gypsum application at $25 \mathrm{Mg} \mathrm{ha}^{-1}$ resulted in a lower $\mathrm{pH}$ of soil compared to the control treatment (Table 3). According to Suswati et al. (2012) sulfate $\left(\mathrm{SO}_{4}{ }^{2-}\right)$ contained in gypsum can reduce the soil $\mathrm{pH}$. The application of gypsum affected simultaneously the decrease of $\mathrm{pH}$, EC, and soil sodicity (Table 3 ). The decrease in soil $\mathrm{pH}$ due to gypsum application was probably due to the combination of more than one factor, mainly the replacement of sodium by calcium and the formation of neutral salts with $\mathrm{SO}_{4}^{2-}$ (Fattah 2014).

The application of gypsum resulted in lower soil EC compared to that in the zeolite and control treatments (Table 3). Purbajanti (2010) reported that the $\mathrm{Ca}$ contained in gypsum will decrease the SAR in saline soil, and $\mathrm{SO}_{4}^{2-}$ will decrease the $\mathrm{pH}$ into neutral condition. Addition of gypsum in saline soil with $\mathrm{pH}$ above 8 results in precipitation of sodium in the form of less soluble sodium sulfate $\left(\mathrm{Na}_{2} \mathrm{SO}_{4}\right)$, resulting in the decrease of soil $\mathrm{pH}$. Gypsum causes the soil rich in $\mathrm{Ca}^{2+}$ and the $\mathrm{Ca}^{2+}$ can replace $\mathrm{Na}^{+}$, which can be leached downward to the deeper soil layers. The $\mathrm{Na}^{+}$ions rapidly decreased by FGD- gypsum application and the soil $\mathrm{pH}$ was thus reduced (Sakai et al. 2012).

The application of zeolite also showed a significant influence $(p<0.05)$ on SAR (Table 3$)$. Application of zeolite at $15 \mathrm{Mg} \mathrm{ha}^{-1}$ can reduce the level of SAR by $24.5 \%$ from 0.33 me $100 \mathrm{~g}^{-1}$ to

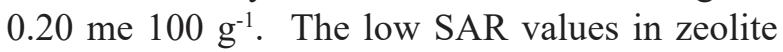
amendment are due to the $\mathrm{Na}^{+}$ions are adsorbed by the zeolite. According to Warmada and Tirtasari (2004), $\mathrm{Ca}^{2+}$ on zeolite site is replaced by $\mathrm{Na}^{+}$from the saline water that contains $\mathrm{NaCl}$, and form $\mathrm{Na}$ zeolite $\left(\mathrm{Na}_{2} \mathrm{Al}_{2} \mathrm{Si}_{3} \mathrm{O}_{10} 2 \mathrm{H}_{2} \mathrm{O}\right)$. The $\mathrm{Na}^{+}$ions from saline water that are adsorbed by zeolite result in the decrease of $\mathrm{Na}^{+}$in the soil, thus the SAR also decreases. Wang et al. (2012) reported that the zeolite used at a solid ratio of $30 \%$ by weight of the soil can reduce the sodium content from $563.0 \mathrm{ppm}$ to $182.7 \mathrm{ppm}$; and SAR from $70.3 \mathrm{me} 100 \mathrm{~g}^{-1}$ to

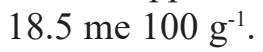

\section{Effects of Gypsum and Zeolite on Nutrient Uptake}

Nitrogen uptake by plants is influenced by soil properties, plant types and stages of plant growth (Fahmi et al. 2010). Gypsum amendment on shallot cultivar Purbalingga (GV2) resulted in the highest yield, which was similar to the effect of zeolite application (Figure 4). According to Suharyani et al. (2012) the application of gypsum can reduce $\mathrm{Na}^{+}$ 


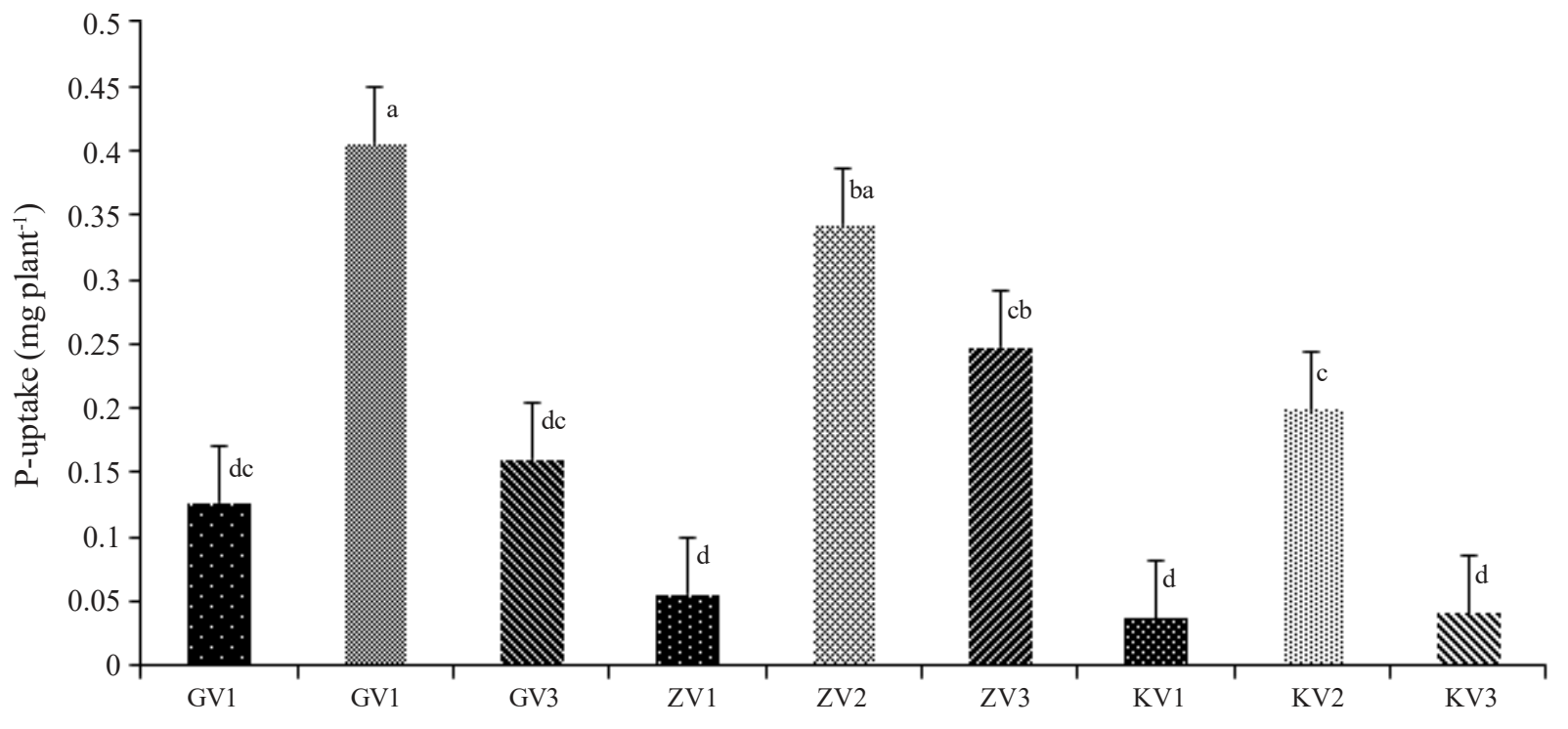

Treatment

Figure 2. The uptake of $\mathrm{P}$ by shallot plants due to the application of gypsum and zeolite. The numbers above the bars followed by the same letters are not significantly different according to DMRT at $5 \%$ significance level. $\mathrm{G}=$ Gypsum $\left(25 \mathrm{Mg} \mathrm{ha}^{-1}\right), \mathrm{Z}=$ Zeolit $\left(15 \mathrm{Mg} \mathrm{ha}^{-1}\right), \mathrm{K}=$ without treatment, V1 = cultivar Brebes, V2 = cultivar Purbalingga, V3 = cultivar Pemalang.

in saline soils which has an effect on the availability of nutrients that can be taken up by the roots of plants. Uptake of nutrients such as nitrate and ammonium in some plants will be reduced due to the presence of $\mathrm{NaCl}$ that can increase the salt level in the soil, which further reduces the activity of nitrate (Parida and Das 2004). According to Sembiring et al. (2005), $\mathrm{N}_{2}$ fixation by biological processes and soil mineralization will be reduced due to excessive absorption of $\mathrm{Na}$.

Phosphorus is one of the macro nutrients, even though the need of $\mathrm{P}$ is not that much as nitrogen and potassium (Rusmarkam and Yuwono 2014). Phosphorus in shallots plays a role in increasing root development, so that it can facilitate and accelerate the absorption of soil nutrients. Phosphorus also plays a role in improving the quality and yield of plants, thus preventing the weight loss of shallot bulbs
(Soepadi 1983 cited by Hamdani 2008). Gypsum amendment at $25 \mathrm{Mg} \mathrm{ha}^{-1}$ was estimated to give a good influence on $\mathrm{P}$ uptake. This is indicated by the high $\mathrm{P}$ uptake by the cultivar Purbalingga applied with gypsum (GV2) (Figure 2). The high P uptake in this treatment can be due to the $\mathrm{Ca}$ in gypsum can bind $\mathrm{P}$ to form Ca-P in the soil, so that $\mathrm{P}$ is not easily leached from the soil. According to Uusitalo et al. (2012) gypsum amendment is effective for erosion control and as a potential technique to reduce the loss of $\mathrm{P}$ from agricultural soils that have high potential for $\mathrm{P}$ loss. Based on Figure 2, it shows that the control treatment resulted in low P uptake by shallot plants. It is suspected that the application of saline water irrigation $\left(2 \mathrm{dS} \mathrm{m}^{-1}\right)$ caused soil salinity so that the P uptake by plants was low. According to Bano and Fatima (2009), soil salinity significantly reduces plant nutrient uptake, especially

Table 4. Effects of amendments on plant height $(\mathrm{cm})$ and bulb diameter $(\mathrm{cm})$ of different shallot cultivars.

\begin{tabular}{lcccccc}
\hline & \multicolumn{5}{c}{ Cultivar } \\
\cline { 2 - 7 } Amendment & \multicolumn{2}{c}{ Brebes } & \multicolumn{2}{c}{ Purbalingga } & \multicolumn{2}{c}{ Pemalang } \\
\cline { 2 - 7 } & $\begin{array}{c}\text { Plant height } \\
(\mathrm{cm})\end{array}$ & $\begin{array}{c}\text { Bulb diameter } \\
(\mathrm{cm})\end{array}$ & $\begin{array}{c}\text { Plant height } \\
(\mathrm{cm})\end{array}$ & $\begin{array}{c}\text { Bulb diameter } \\
(\mathrm{cm})\end{array}$ & $\begin{array}{c}\text { Plant height } \\
(\mathrm{cm})\end{array}$ & $\begin{array}{c}\text { Bulb diameter } \\
(\mathrm{cm})\end{array}$ \\
\hline Gypsum $(\mathrm{G})$ & $16.7 \mathrm{a}$ & $1.67 \mathrm{a}$ & $17.0 \mathrm{~b}$ & $2.00 \mathrm{ab}$ & $14.3 \mathrm{~b}$ & $1.58 \mathrm{ab}$ \\
Zeolit $(\mathrm{Z})$ & $17.0 \mathrm{a}$ & $1.30 \mathrm{a}$ & $18.0 \mathrm{ab}$ & $2.15 \mathrm{a}$ & $23.7 \mathrm{a}$ & $1.80 \mathrm{a}$ \\
without $(\mathrm{K})$ & $13.4 \mathrm{~b}$ & $1.46 \mathrm{a}$ & $20.2 \mathrm{a}$ & $1.59 \mathrm{~b}$ & $14.9 \mathrm{~b}$ & $1.25 \mathrm{~b}$ \\
\hline
\end{tabular}

Note: The numbers followed by the same letters in the same column are not significantly different by DMRT at $5 \%$ significance level. 


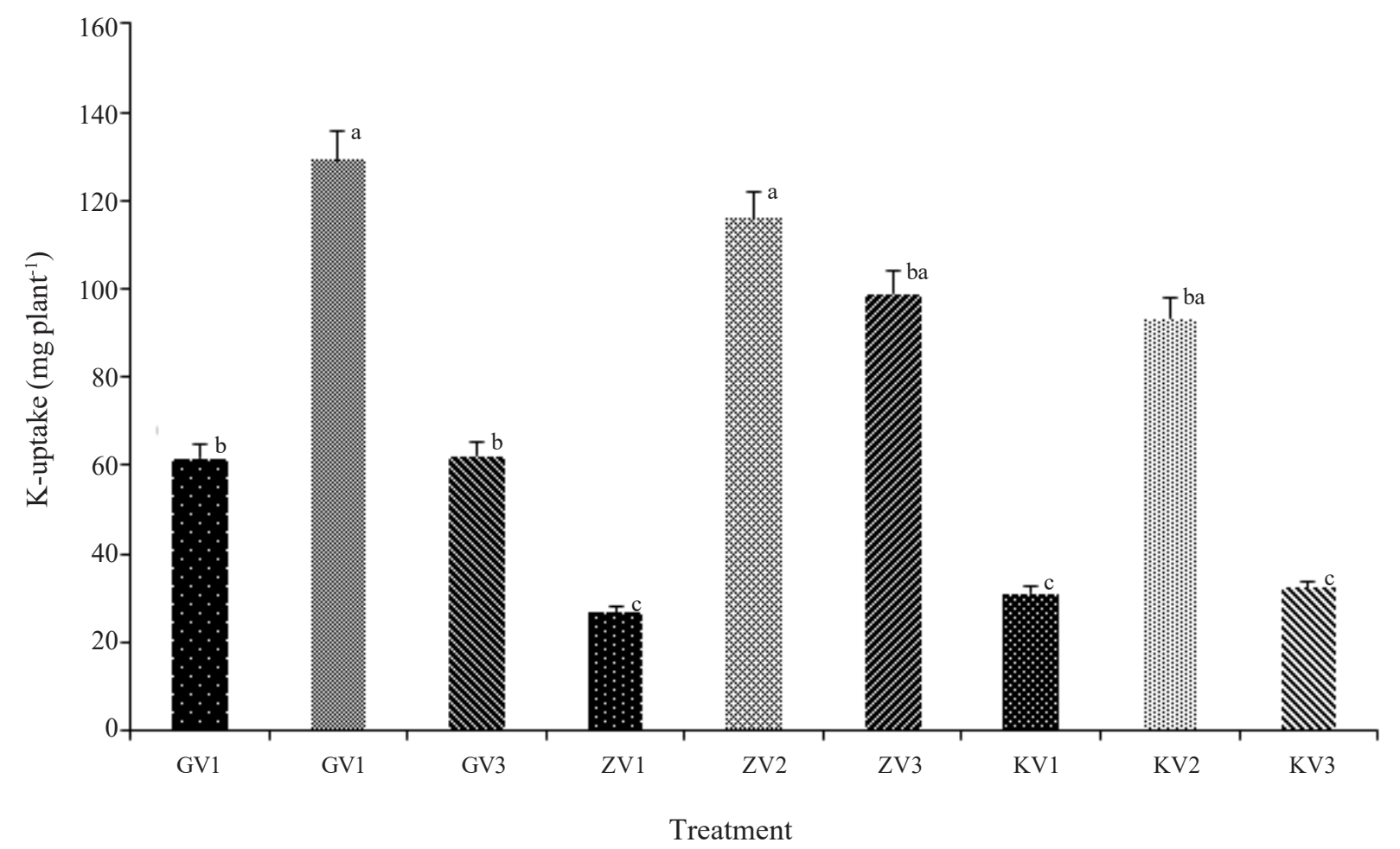

Figure 3. The uptake of K by shallot plants due to the application of gypsum and zeolite. The numbers above the bars followed by the same letters are not significantly different according to DMRT at 5\% significance level. $\mathrm{G}=$ Gypsum $\left(25 \mathrm{Mg} \mathrm{ha}^{-1}\right), \mathrm{Z}=$ Zeolit $\left(15 \mathrm{Mg} \mathrm{ha}^{-1}\right), \mathrm{K}=$ without treatment, $\mathrm{V} 1$ $=$ cultivar Brebes, V2 = cultivar Purbalingga, V3 = cultivar Pemalang.

phosphorus $(\mathrm{P})$ because phosphate ions are precipitated by $\mathrm{Ca}$ ions in salt-affected soil.

Shallot plants take up more amounts of K than other plants (Jones et al. 1991), since potassium helps in the development of bulb cells and osmotic pressure in plants. One problem of plants grown on saline soils is the absorption of $\mathrm{K}^{+}$. The uptake competition between $\mathrm{Na}^{+}$ions and $\mathrm{K}^{+}$ions causes high absorption of $\mathrm{Na}^{+}$will inhibit absorption of $\mathrm{K}^{+}$ (Amir et al. 2017). Applying saline irrigation (2 dS $\mathrm{m}^{-1}$ ) continuously leads to the $\mathrm{Na}^{+}$and $\mathrm{Cl}^{-}$ accumulation in the soil. Accumulation of salt inhibits the absorption of nutrients and water by plants. The highest $\mathrm{K}$ uptake was measured in the treatment of gypsum amendment on cultivar Purbalingga (GV2). This is presumably because the gypsum amendment was able to reduce $\mathrm{Na}^{+}$and $\mathrm{Cl}^{-}$deposits in saline soil. Wakeel (2013) reported that the $\mathrm{K}^{+}$uptake by plants is affected by the presence of $\mathrm{Na}^{+}$, because $\mathrm{K}^{+}$and $\mathrm{Na}^{+}$are similar in physicochemical properties, therefore, $\mathrm{Na}^{+}$competes with $\mathrm{K}^{+}$in plant uptake. Low level of $\mathrm{Na}^{+}$in soil applied with gypsum can be seen in Figure 1. According to Wahyuningsih et al. (2017), addition of $2.5 \mathrm{Mg} \mathrm{ha}^{-1}$ gypsum to soil with a salinity of $3.2 \mathrm{dS} \mathrm{m}^{-1}$ results in better potassium content in the canopy of green bean plants. In this study the addition of $25 \mathrm{Mg} \mathrm{ha}^{-1}$ gypsum to soil with a salinity of $2 \mathrm{dS} \mathrm{m}^{-1}$ showed a positive influence on the uptake of potassium.

\section{Effects of Gypsum and Zeolite on Plant Growth}

Application of gypsum and zeolite had no significant effects on the growth of different shallot cultivars $(p>0.05)$. Cultivar Pemalang applied with zeolite amendment at $15 \mathrm{Mg} \mathrm{ha}^{-1}$ resulted in the highest plant of $23.66 \mathrm{~cm}$ (Table 4). The measurement of plant height was carried out from the lower part of the plants just above the ground to the highest leaf tip. The application of zeolite in saline soil is able to control the available of $\mathrm{Na}$ at the low level, thus the plant can grow well. Purbalingga cultivar with zeolite treatment (ZV2) had the highest average bulb diameter (Table 4). The application of zeolite is considered to give a good effect on the shallot growth, because zeolite is able to bind $\mathrm{Na}^{+}$from the soil applied with saline irrigation $\left(2 \mathrm{dS} \mathrm{m}^{-1}\right)$. Maleki et al. (2012) reported that the use of zeolite at $15 \mathrm{Mg} \mathrm{ha}^{-1}$ in saline soil increased the height of cassava plants by $7.08 \%$ and weight per plant by $14.51 \%$. Addition of amendment also improved nutrient uptake by plant. According to Wahyudi (2009), improvement in soil conditions led to better growth and development of plant roots, thereby increasing nutrient uptake and improving plant 


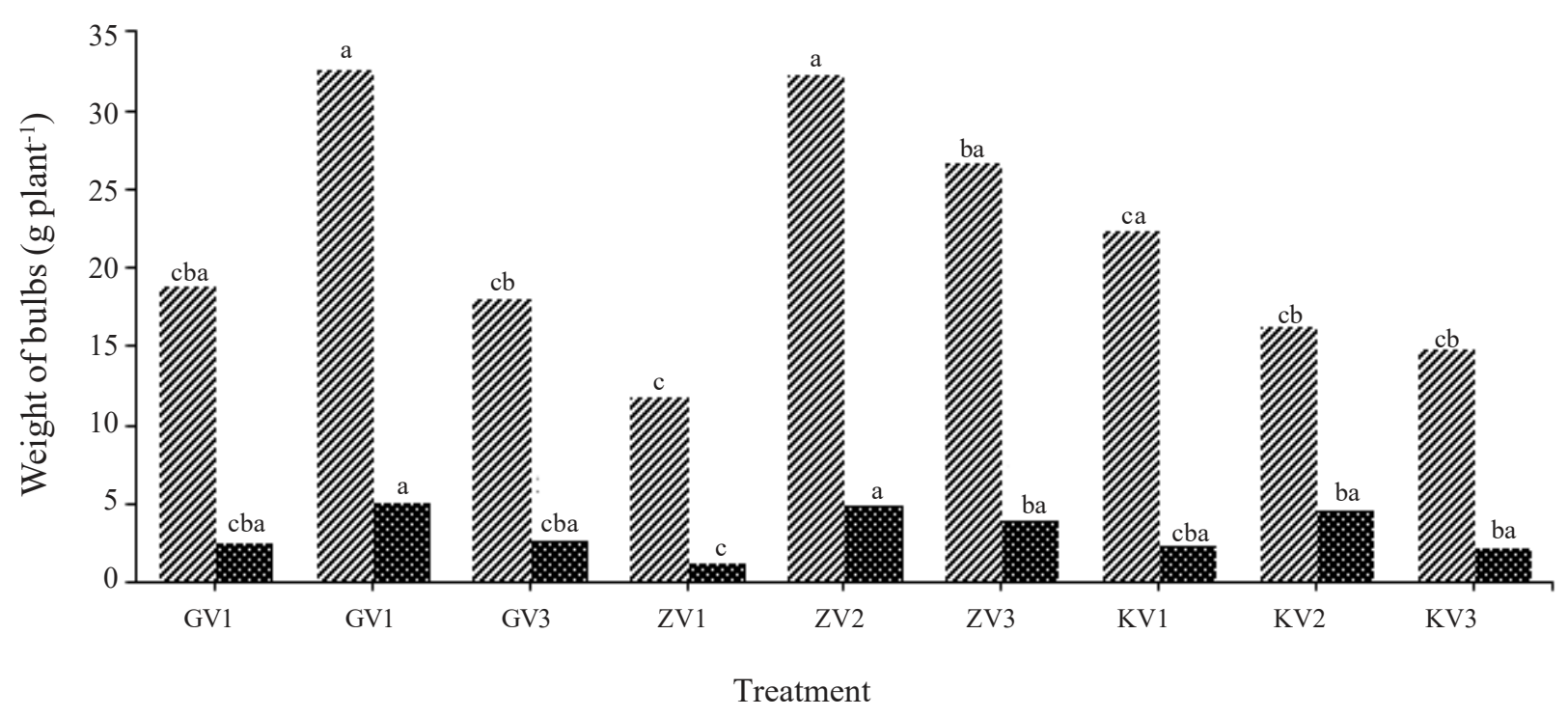

Figure 4. Fresh and dry weight of bulbs due to the application of gypsum and zeolite. The numbers above the bars followed by the same letters are not significantly different by DMRT at $5 \%$ significance level. $\mathrm{G}=\operatorname{Gypsum}\left(25 \mathrm{Mg} \mathrm{ha}^{-1}\right), \mathrm{Z}=$ Zeolit $\left(15 \mathrm{Mg} \mathrm{ha}^{-1}\right), \mathrm{K}=$ without treatment, $\mathrm{V} 1$ = cultivar Brebes, V2 = cultivar Purbalingga, V3 = cultivar Pemalang. " : Fresh bulbs weight; $\mathbf{z}:$ Dry bulb weight.

growth. Setiyowati et al. (2010) reported that the larger bulb diameter indicates that the contents of organic compounds, such as carbohydrates, proteins, fats, etc. in the bulbs are high, so the compounds contained in the shallots with higher dry weight are also relatively high.

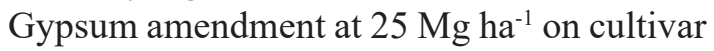
Purbalingga (GV2) resulted in the highest fresh weight and dry weight of bulbs compared to the other treatments (Figure 4). The high fresh weight of bulbs was due to the nutrient uptake in the treatment was high. The high fresh weight of shallots indicates a high level of water content in plants, this will cause the bulb size to be larger. The bulb weight showed a positive correlation with the bulb diameter $(\mathrm{r}=0.79)$. According to Setiyowati et al. (2010), the increase of bulb fresh weight is due to the large amount of water taken up and the accumulation of photosynthesis in leaves are translocated for bulb formation. The application of gypsum amendment at $25 \mathrm{Mg} \mathrm{ha}^{-1}$ to cultivar Purbalingga (GV2) showed better amount of nitrogen and phosphorus uptake by shallot plants than the other treatments. According to Firmansyah and Sumarni (2013) high nitrogen uptake by shallot plants causes higher plant dry weight and yield. Sumarni et al. (2012) reported that the increase of $\mathrm{N}, \mathrm{P}$ and $\mathrm{K}$ uptake in plants can stimulate better plant growth (plant dry weight). This is because one that affects the dry weight of plants is the optimal photosynthesis. Photosynthesis can result in an increase in plant dry weight due to $\mathrm{CO}_{2}$ uptake. This is because the dry weight of plants is a net accumulation of $\mathrm{CO}_{2}$ assimilation during the growth period (Dwijoseputro 1994). So that, if the $\mathrm{N}$ uptake is high, the dry weight of bulbs will also increase.

\section{CONCLUSIONS}

Saline incubation and saline irrigation on soil significantly increased soil $\mathrm{pH}, \mathrm{EC}$ and $\mathrm{SAR}$, while gypsum and zeolite application decreased $\mathrm{pH}, \mathrm{EC}$ and SAR. Gypsum application at $25 \mathrm{Mg} \mathrm{ha}^{-1}(\mathrm{G})$ significantly increased $\mathrm{N}, \mathrm{P}$ and $\mathrm{K}$ uptake by shallot plants and was more effective on cultivar Purbalingga. The highest nutrient uptake was measured in the treatment of gypsum at $25 \mathrm{Mg}$ ha${ }^{1}$ on cultivar Puralingga (V2), therefore significantly increased the shallot bulb diameter, and fresh and dry weight of bulbs. The highest plant was measured in the treatment of zeolite at $15 \mathrm{Mg} \mathrm{ha}^{-1}$ on cultivar Pemalang (V3).

\section{ACKNOWLEDGEMENTS}

This work is supported by the Ministry of Education and Culture of the Republic Indonesia under Research Grant of Strategy National 2017.

\section{REFERENCES}

Agus F and IGM Subiksa. 2006. Soil Nutrient Status Affected by Tsunami Mud and Its Management Implications. Soil Research Institute. 
Amezketa E, R Aragues and R Gazol. 2005. Efficiency of sulfuric acid, mined gypsum, and two gypsum byproducts in soil crusting prevention and sodic soil reclamation. Agron J 97:983-989.

Amir B, M Naim and E Sudartik. 2017. Application of Palm Oil Waste Effect on the Formation of Root Oils and the Results of Cowpea (Vigna Unguiculata L) When Accumulated by Salinity. J Perbal 5: 1-10.

Atikah WS. 2017. The Potentiality of Activated Natural Zeolite From Gunung Kidul as Adsorbent To Textile Dyes. J Ilmiah Arena Textile 32: 17-24.

Bano A and M Fatima. 2009. Salt Tolerance in Zea Mays (L). Following Inoculation with Rhizobium and Pseudomonas. Biol Fertil Soils 45: 405-413.

Buol SW. 2005. Tropical Soils Humid Tropical. In Encyclopedia of Soils in the Environment.

Cardon JG, TA Davis, Bauder and RM Waskom. 2003. Managing Saline Soils. Colorado State University, U.S. Department of Agriculture and Colorado.

Central Bureau of Statistics of Central Java Province. 2017.

Dwidjoseputro D. 1994. Introduction to Plant Physiology. Jakarta: Gramedia.

Evianti and Sulaeman. 2012. Analysis Chemistry of Soil, Plants, Water and Fertilizers. Balitannah. Bogor.

Fahmi A, Syamsudin, S Utami and B Radjagukguk. 2010. Effect of Nitrogen and Phosphorus Nutrient Interactions on Growth of Corn Plants (Zea Mays L) in Regosol and Latosol Soils. Biologist News I 10 (3) : 297-304

Fattah MK. 2014. Role of gypsum and compost in reclaiming saline-sodic soils. IOSR J Agric Vet Sci 1:30-38.

Firmansyah I and N Sumarni. 2013. The Effect of Fertilizer Doses and Varieties on Soil pH, N-Total Soil, N Absorption, and Shallot (Allium Ascalonicum L.) Results in Central Java Entisols-Brebes Soil. J Hort 23:358-364.

Franzen D, G Rehm and J Gerwing. 2006. Effectiveness of Gypsum in the North-Central Region of the U.S. North Dakota State University.

Haisheng H, W Wagjie, Z Hong, Z Yuangang, Z Zhonghua, G Yu, X Huinan and Y Xingyang. 2008. Influence of addition of different krilium in salinesodic soil on the seed germination and growth of cabbage. Acta Ecologia Sinica 28: 5338- 5346.

Hamdani JS. 2008. Growth and Yield of Yellow Cultivar in Yellow Status Nutrient Total Soil And Different Doses of Phosphate Fertilizer. J Agric 1: 42-49.

Hendrayana H. 2002. Saltwater Intrusion Into Aquifers in the Mainland. Geological Engineering Dept., Faculty of Engineering, Gadjah Mada University.

Jarman J. 2013. Applying Gypsum As A Soil Amendment. Agricultural Electonic Bulletin Board 19.

Jones JB, B Wolf and HA Mills. 1991. Plant Analysis Hand Book, Micro-Macro Publishing, Inc.

Koswara E. 2007. Testing Techniques Results of Some Shallot Varieties in South Sumatra Tidal Land. Agric Eng Bul 12: 1-3.
Kristanto AH and Purwono. 2017. The Modification of Cultivation For Decreasing Salinity In Sugarcane (Saccharum Officinarum L.) Dryland in Cepiring Kendal. Bul Agrohorti 5: 351-358.

Lebron I, DL Suzrez and T Yoshida. 2006. Gypsum effect on the aggregate size and geometry on three sodic soils under reclamation. Soil Sci Am J 66: 92-98.

Lubis AT, Z Nasution and Sarifuddin. 2013. The Effect of Sea Water, Zeolite, and Volcanic Sand on Nutrient Status in Peat Soils and Paddy Rice Growth and Production. J Agroecotechnology 2: 13-25.

Maleki S, AN Moghaddam, H Sabbaghpour, AA Noorinia and H Sabouri. 2012. Effects of Zeolite and Potassium on Yield and Yield Components of Chickpea (Cicer Arietinum L.) in the Different Irrigation Regimes. Adv in Biores 7: 119-127.

Micu D, C Proca, C Ioana, C Podaru and G Burtica. 2005. Improvement Possibilities of Soil Quality. Chem Bull 'POLITEHNICA' 50: 108-111.

Muharam and A Saefudin. 2016. The Effect of Various Soil Enhancers on the Growth and Population of Paddy Rice Plants (Oryza Sativa L) Dendang Varieties in New Open Salin Rice Soils. Indonesian Agrotech J1: 141-150.

Parida AK and AB Das. 2004. Effects of $\mathrm{NaCl}$ Stress on Nitrogen and Phosphorous Metabolism in A True Mangrove (Bruguiera Parviflora) Grown Under Hydroponic Culture. J Plant Physl 161: 921-928.

Provin T and J1 Pitt. 2017. Managing Soil Salinity. Texas A \& M Agrilife Extension Service. Page 1-5.

Purbajanti E, R Soetrisno, E Hanudin and S Budhi. 2010. The Appearance of Physiology and the Result of Bengal Grass (Panicum Maximum Jacq.) In Saline Soil Due to Provision of Manure, Gypsum and Nitrogen Sources. J Indonesian Agric Sci 12: 61-67.

Rahayu, G-M Yang and J-S Choi. 2011. Effects of Several Amendment Materials on Salt Accumulation and Kentucky Bluegrass (Poa pratensis L.) Growth in Sand Growing Media Established Over the Reclaimed Saline Soil. Asian J Turfgrass Sci 25: 208-216.

Rosmarkam A and NW Yuwono. 2014. The Science of Soil Fertility. Kanisius. Pp. 1-224.

Sembiring H, A Gani And T Iskandar. 2005. Implications of Salinity Research in Aceh for Indonesian Rice Growing. Pp. 97-108. In: F Agus and G Tinning (eds). Proc. of Inter. Workshop on Post Tsunami Soil Manag. 180p.

Setiyowati, S Haryanti and RB Hastuti. 2010. Effect of Differences in Concentration of Tea Liquid Organic Fertilizer on Production of Shallots (Allium Ascalonicum L.). Biome 12: 44-48.

Sudarmi 2013. The Importance of Micro Nutrients for Plant Growth. Widyatama 22: 178-183.

Suharyani F, Kusmiyati and Karno. 2012. The Effect of Saline Soil Improvement Method on Nitrogen and Phosphorus Absorption of Bengal Grass (Panicum Maximum). Animal Agric J 1: 168-176. 
Sumarni N, R Rosliani and RS Basuki. 2012. The Growth Response, Results of NPK Nutrient Uptake for Shallot Plants Against Various Doses of NPK Fertilization in Alluvial Soils. Horticultural J 22: 366-375.

Suswati, Sumarsono and F Kusmiyati. 2012. Growth and Production of Bengal Grass (Panicum Maximum) in Various Efforts to Repair Soil Saline. Animal Agric $J 1: 297-306$.

Uusitalo R, K Ylivainio, J Hyvaluoma, K Taste, J Casease, P Nylund, L Pietola and E Turtola. 2012. The Effects of Gypsum the Transfer of Phosphorus and Other Nutrients Through Clay Soil Monoliths. Agric Food Sci21:260-278.

Wahyudi I. 2009. N Absorption of Corn (Zea Mays L.) Due to the Provision of Green Lamtoro Fertilizer on Ultisol Wanga. J Agroland 2: 5-1.
Wahyuningsih S, A Kristiono and A Taufiq. 2017. Effect of Ameliorant Type on Growth and Yield of Mung Beans in Saline Land. Palawija Bul 15: 69-77.

Wakeel A. 2013. Potassium-sodium interaction in soil and plant under saline-sodic conditions. J Plant Nutr Soil Sci 176: 344-354

Wang X, O Ozdemir, Ma Hampton, AV Nguyen and DD Do. 2012. The Effect of Zeolite Treatment by Acids on Sodium Adsorption. Ratio of Coal Seam Gas Water. J Water Res 46: 524- 525.

Warmada W and AD Titisari. 2004. Agromineralogy (Mineralogy for Agricultural Sciences. Department of Geological Engineering, UGM Faculty of Engineering, pp. 1-75. 